\title{
Myogenic and Melanotic Differentiated Medulloblastoma: Case Report
}

\section{Miyojenik ve Melanotik Differansiyasyonlar İceren Medulloblastoma: Olgu Suпити}

\author{
Alp Ozgun BORCEK ${ }^{1}$, Emre DURDAG ${ }^{1}$, Hakan EMMEZ $^{1}$, Gokhan KURT ${ }^{1}$, M. Kemali BAYKANER ${ }^{2}$ \\ ${ }^{1}$ Gazi University, Faculty of Medicine, Department of Neurosurgery, Ankara, Turkey \\ ${ }^{2}$ Gazi University, Faculty of Medicine, Department of Neurosurgery Division of Pediatric Neurosurgery, Ankara, Turkey
}

Correspondence address: Emre DURDAG / E-mail: emredurdag@yahoo.com

\begin{abstract}
Medulloblastoma is the most common malignant tumor of childhood and usually arises from the cerebellar vermis. Several histological types of medulloblastoma have been described. Myogenic and melanotic differentiated medulloblastoma are seldom seen. We present a case diagnosed as myogenic medulloblastoma with focal areas of melanotic differentiation. A 4-year-old boy was admitted due to headache, nausea and vomiting for a month. MRI revealed a heterogeneous enhanced posterior fossa tumor rising from the fourth ventricle. He was operated and pathological examination of the specimen revealed myogenic medulloblastoma with myogenic and melanotic differentiation. According to our knowledge there are six cases reported in the literature so far. Oncogenic factors in medulloblastoma development are controversial. Presence of multiple differentiation patterns supports a pluripotent origin for these tumors.
\end{abstract}

KEYWORDS: Medulloblastoma, Myogenic, Melanotic, Childhood

öz

Medulloblastoma serebeller vermisden köken alan çocukluk çağı maligniteleri arasında sık görülen bir tümördür. Pek çok histolojik alt tipi tanımlansa da miyojenik ve miyojenik differansiyasyonun aynı anda saptanması nadir bir histopatolojik durumdur. Burada melanotik adalar içeren miyojenik şekilde differansiyasyon gösteren medulloblastoma tanısı alan bir vakamızı sunmak istedik 4 yaşında erkek çocuk başağrısı, bulantı, kusma ile kliniğe başvurdu ve yapılan MR incelemede 4. ventrikülü dolduran heterojen kontrastlanan bir posterior fossa tümörü saptandı. Opere edilen hastanın histopatolojik tanısı melanotik differansiyasyonlar içeren miyojenik medulloblastoma olarak geldi. Bilgimize göre benzer histopatolojik tanıya sahip 6 hasta daha önce literatürde tanımlanmıştır. Medülloblastoma oluşumunda etken onkolojik faktörler tartışmalı iken çoklu differansiyasyonun bir arada olması tümörlerin pluripotent orjinini akla getirmelidir.

ANAHTAR SÖZCÜKLER: Medulloblastoma, Miyojenik, Melanotik, Çocukluk çağı

\section{INTRODUCTION}

Medulloblastoma was first named after Bailey and Cushing in 1925 and described as an aggressive, highly malignant small cell tumor of midline cerebellum (9). Although they are rare tumors in adulthood, medulloblastoma is the most common malignant central nervous system tumor of the childhood and the most common primitive neuroectodermal tumor (PNET). Approximately $20 \%$ of these tumors are seen under the age of $19(3,9,14,16)$. These neuronal differentiated embryonal tumors are usually diagnosed in the first decade of life with a male preponderance. Although the majority occurs sporadically, hereditary conditions have been associated with medulloblastoma, including Gorlin syndrome (nevoid basal cell carcinoma syndrome), Rubinstein-Taybi syndrome, ataxia telangiectasia, Turcot syndrome (e.g. glioma polyposis syndrome), Li-Fraumeni syndrome, neurofibromatosis and tuberous sclerosis (9).
Medulloblastomas arise from inferior medullary velum of the cerebellar vermis and may cause symptoms of raised intracranial pressure and truncal or appendicular ataxia. Occlusion of the fourth ventricle worsens the clinical course due to obstructive hydrocephalus. The child's common complaints consist of the classical triad of morning headaches, vomiting and lethargy. Craniospinal spread via cerebrospinal fluid (CSF) can be seen.

We present a case diagnosed as myogenic medulloblastoma with focal areas of melanotic differentiation

\section{CASE REPORT}

A 4-year-old boy was admitted to our clinic after headache, nausea and vomiting attacks. He was complaining of diplopia for a week. He had a gait ataxia and abducens nerve palsy on the left side in his neurological examination. Computerized tomography and gadolinium enhanced cranial magnetic 
resonance imaging (MRI) revealed a heterogeneous enhanced posterior fossa tumor rising from the fourth ventricle (Figure 1). The size of the ventricles was normal and there was no sign of hydrocephalus. There was no metastatic seeding to the spinal cord in his spinal MRI. He was operated and a gross total resection was achieved. He developed lethargy and upward gaze palsy on the fifth day of the operation. Computed tomography revealed tri-ventricular hydrocephalus. He was operated again and a ventriculo-peritoneal shunt was inserted. The post-shunting course was uneventful.

Microscopic examination revealed a poorly differentiated tumor composed of sheets of small-to-medium sized cells with focally molded, hyperchromatic nuclei and scanty cytoplasm (Figure 2). Numerous apoptotic cells and mitotic figures were observed. Some of the tumor cells contained finely granular brown pigment consistent with melanin (Figure 3). A different proportion of cells forming nests and exhibiting rhabdoid appearance with eccentric, bright eosinophilic cytoplasm were identified as well (Figure 4). These cells were immunohistochemically positive for desmin, muscle specific actin and myogenin (Figure 5A-C). GFAP, HMB45, S-100, neurofilament, NSE, chromogranin, synaptophysin, vimentin, EMA and pancytokeratin were focally positive throughout the tumor. The final histopathologic diagnosis with these findings was medulloblastoma with myogenic and melanocytic differentiation.

He was transferred to pediatric oncology clinic for further adjuvant therapy.

\section{DISCUSSION}

Medulloblastoma is believed to arise from precursor cells of the external granular layer of the developing cerebellum and is predominantly composed of densely packed cells with round-to-oval hyperchromatic nuclei with generally abundant mitotic activity (11). They account for $40 \%$ of all posterior fossa tumors in children and they represent only $0.5-1 \%$ of all intracranial neoplasms in adults. The classic subtype represents $80 \%$ of all medulloblastoma cases. The other subtypes are, however, rather uncommon (16).

The classification proposed by the World Health Organization (WHO) in 2000 describes subtypes of medulloblastoma as classic, desmoplastic, large cell, medullomyoblastoma and melanotic medulloblastoma (14-16). The classification was revised in 2007 and there have been changes in medulloblastoma classification. The new system defines subtypes of medulloblastoma as desmoplastic/nodular medulloblastoma, medulloblastoma with extensive nodularity, anaplastic medulloblastoma and large cell medulloblastoma.

The term of medullomyoblastoma was first used in 1933 by Marinesco and Goldstein and, up to now approximately 50 cases have been reported in the literature $(12,14)$. They originate from the vermis and demonstrate similar clinical behavior to classical medulloblastomas. The management protocol of this subtype is similar to the classical ones. Histologically these medulloblastomas include areas focally exhibiting rhabdomyoblastic differentiation which can be demonstrated with immunohistochemical stains for myogenin, desmin and actin. Primitive sarcomeres and Z-bands might also be observed in electron microscopy (14).

The 2000 WHO classification named medulloblastoma with myogenic differentiation as medullomyoblastoma. However, since its clinical and genetic features are similar to those of other medulloblastoma, this lesion is no longer considered as a distinct entity. The authorities suggest the term "medulloblastoma with myogenic differentiation" for any variant containing focal rhabdomyoblastic elements with immunoreactivity to desmin, myoglobin and fast myosin (11).
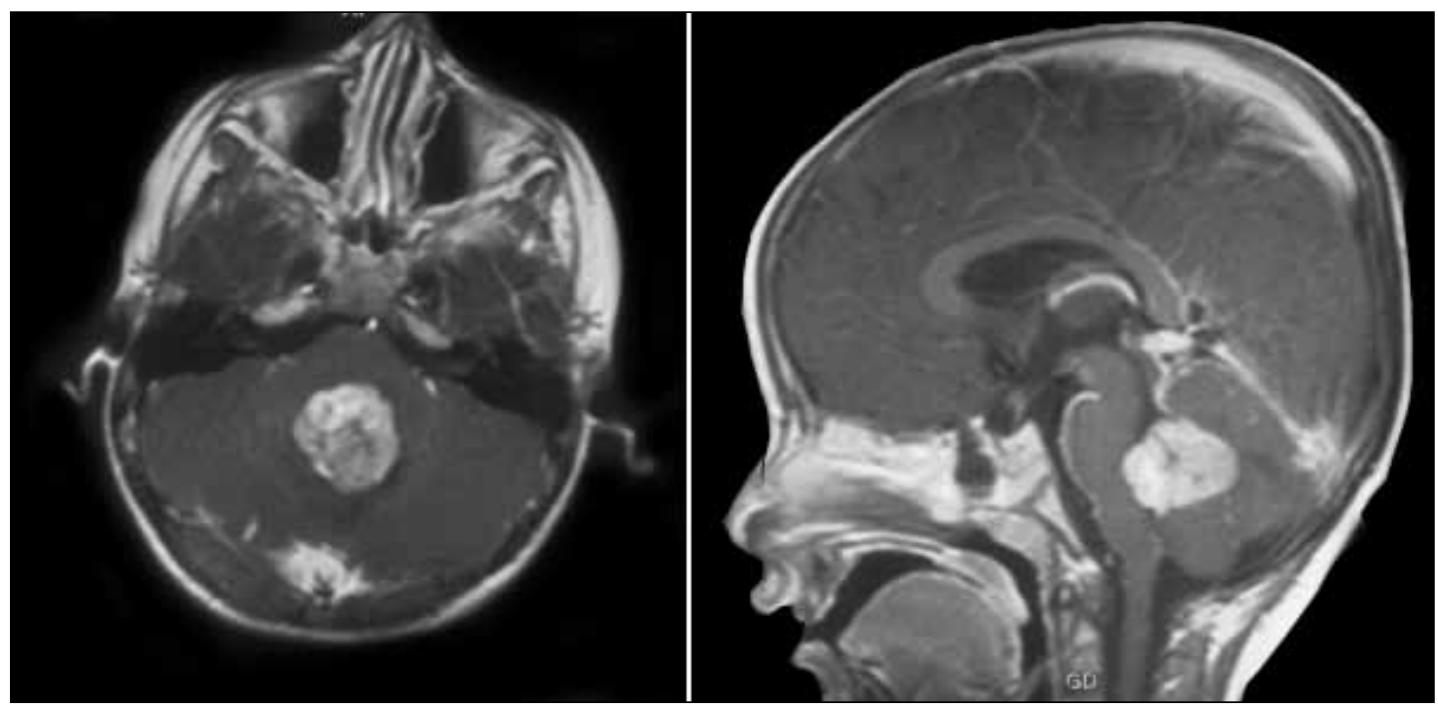

Figure 1: Preoperative MRI demonstrating the fourth ventricular mass. 


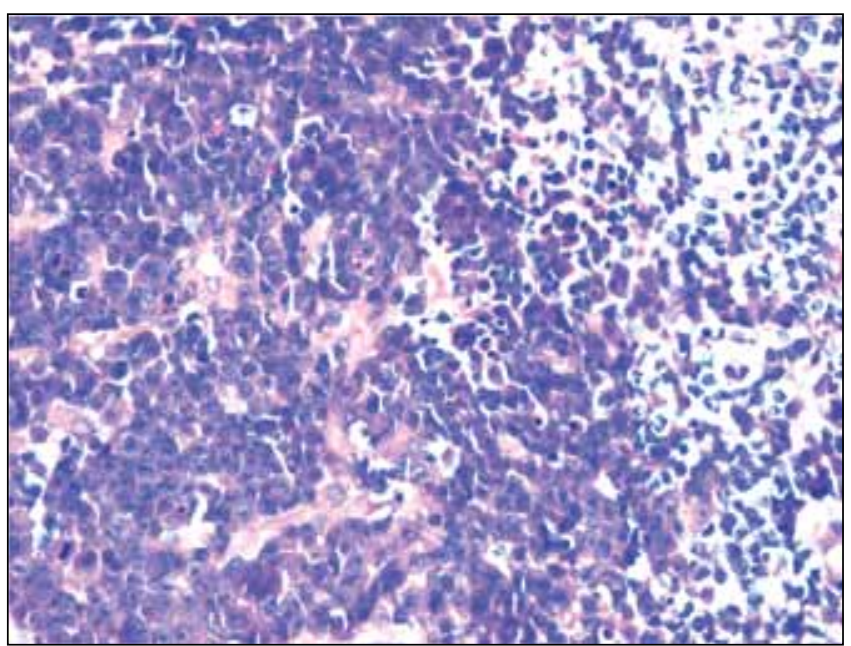

Figure 2: Embryonal cells with hyperchromatic nuclei and scanty cytoplasm. Note the apoptotic cells and mitoses in the background (Hematoxylin-eosin X200).

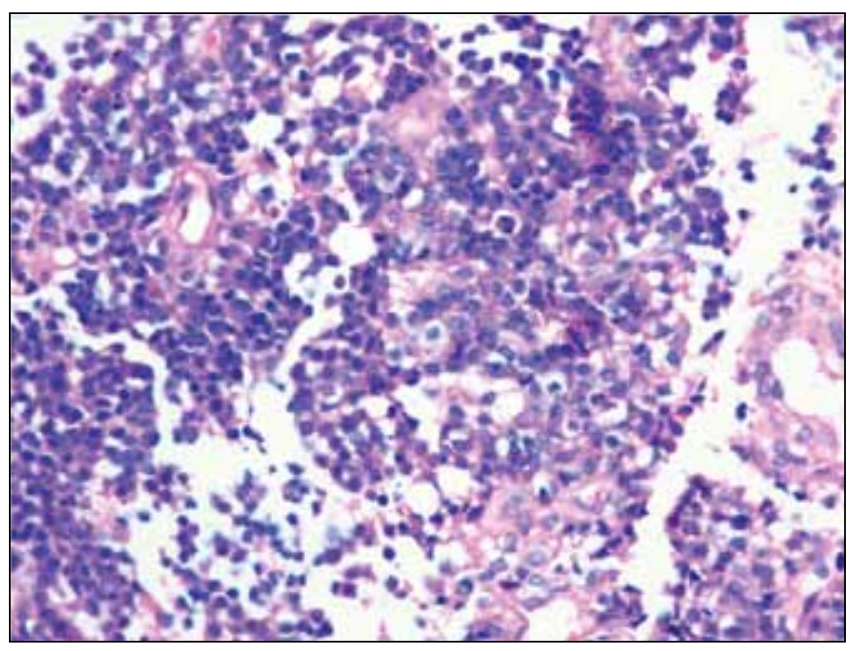

Figure 3: Melanin containing cells (Hematoxylin-eosin X200).

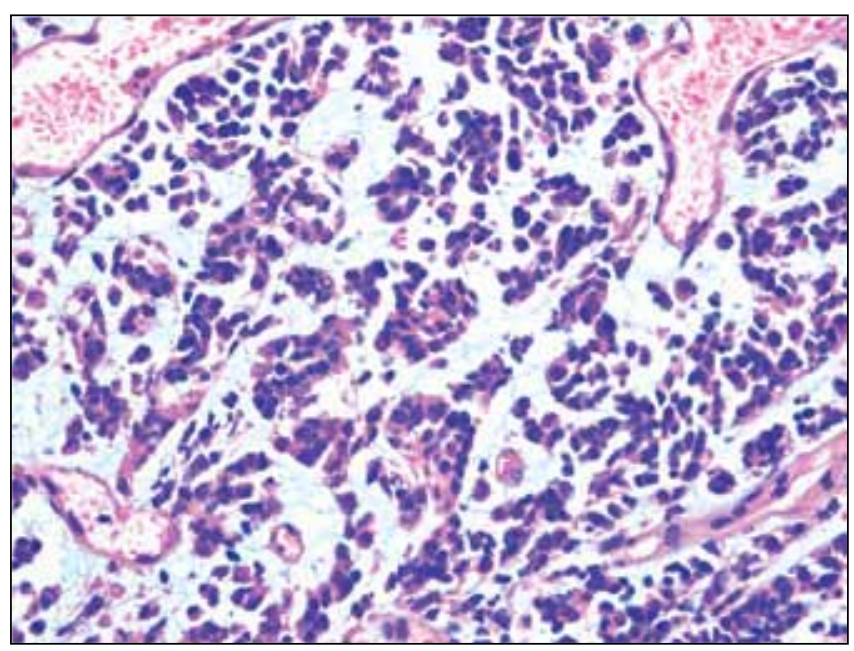

Figure 4: Nests of rhabdoid cells with eccentric eosinophilic cytoplasm in a myxoid background (Hematoxylin-eosin X100).
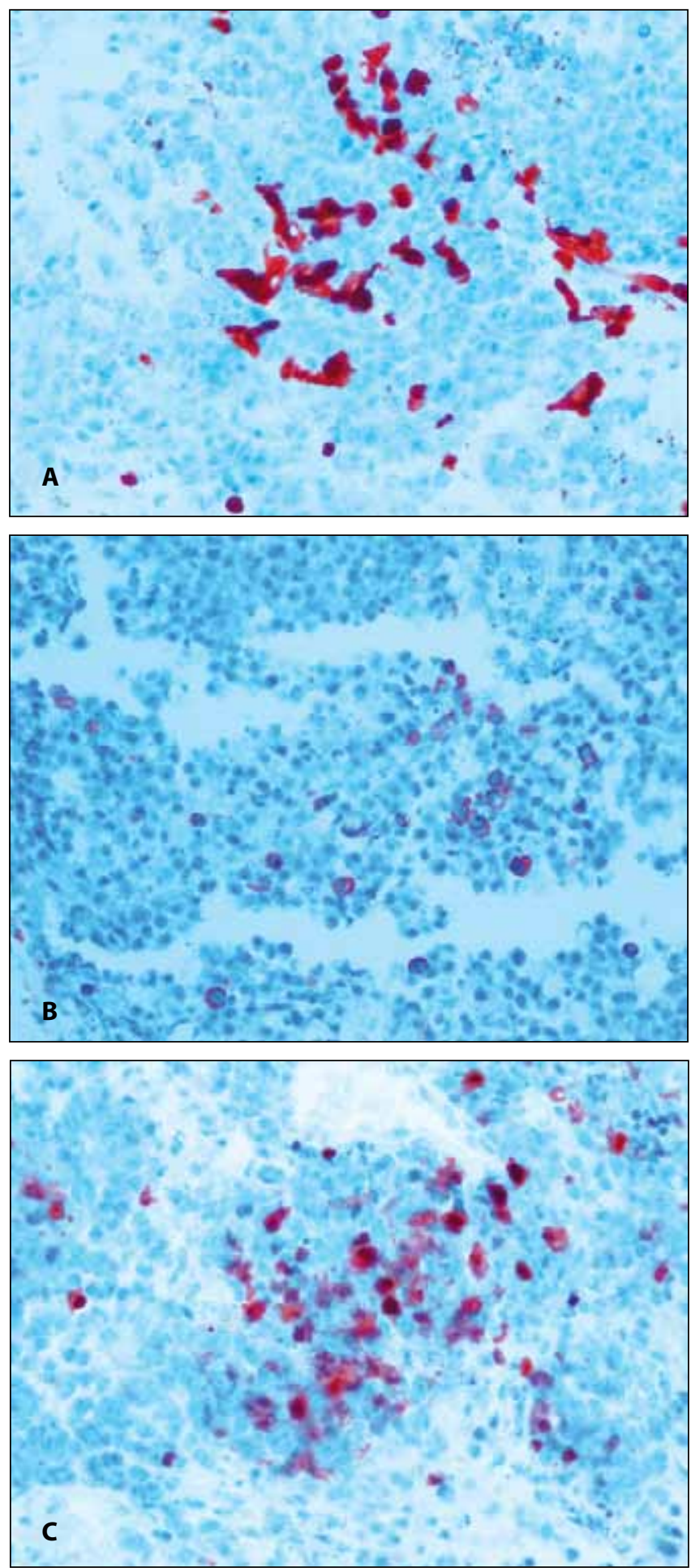

Figure 5: A) Immunohistochemical positivity with desmin, B) actin and C) myogenin.

Melanotic medulloblastoma was first described in 1962 by Fowler and Simpson as 'pigmented melanin forming tumor of cerebellum'. Since then approximately 12 cases have been reported in literature $(14,15)$. 
The fate of the term melanotic medulloblastoma is the same. The new classification no longer recognizes this subtype as a distinct entity and instead suggests the term "medulloblastoma with melanotic differentiation" for tumors that appear undifferentiated or epithelial, with formation of tubules or papillae and expressing S-100 protein (11). Tumors possessing both myogenic and melanotic differentiation was reported only in six papers up to date $(2,7,8,12,13,14)$. The mean age of those were 4 . They usually arise from cerebellar vermis or the 4 th ventricle (14).

Banerjee and Duinkere have reported first examples of these tumors in 1973 and 1981, respectively $(2,7)$. Sakata et al have presented a 6 year old boy with a classical medulloblastoma demonstrating melanotic and myogenic differentiation as well as neuronal and astrocytic differentiation. They conclude that their case supports the multipotent origin of neuroblastomas (15). Kalimo et al have reported a 5 year old girl with a PNET demonstrating neuronal, astrocytic, melanotic and myogenic differentiation. The child has suffered from rapid recurrence and died on the 6th month of primary surgery. In their conclusion they site the most widely accepted theory in oncogenesis of medulloblastomas which is the multipotent origin from the neural crest (8). Polydorides et al have reported a large cell medulloblastoma with myogenic and melanotic differentiation in a 2-year-old boy. The have supported their diagnosis with genetic investigation. They concluded their discussion in agreement with the updated WHO classification that these tumors are histologic patterns of medulloblastoma with similar prognostic features (14). Nozza et al. have described a cerebellar medullomyoblastoma with melanotic tubular structures in a 2 year old boy. They discussed the possibility of a teratomatous origin of the tumor but concluded in favour of the theory that undifferentiated neuroepithelial cells differentiate along myogenic lines (13).

Mehta et al have reported a 3-year-old girl presenting with insidious dysarthria, urinary incontinence and walking difficulty. The symptoms were due to a pigmented myomedulloblastoma. The authors emphasize the importance of differential diagnosis including pediatric tumors demonstrating rhabdoid differentiation and teratomas. They conclude that besides the best available treatment modalities the prognosis is poor (12).

The histogenesis of medulloblastomas with myogenic differentiation is controversial. According to a view, these tumors originate form pluripotent cells of the fetal cerebellar meninges (12). Another view is that myoblastic cells originate from neoplastic transformation of endothelial cells based on the fact that these muscle fibers were located around blood vessels and showed mitotic figures $(1,10)$.

One important entity is medullamyoblastomas demonstrating teratomatous elements. Although some believe that these tumors are actual teratomas, absence of endodermal elements and mesenchymal elements other than muscle fibers excludes this option $(5,15)$.
For melanotic medulloblastomas, the histogenesis is even more controversial. Some authors consider these tumors as variants of melanotic neuroectodermal tumors of infancy. However, these tumors are not as aggressive as medulloblastomas (6). Another suggestion is that melanotic medulloblastomas are hybrid tumors: pigmented cells are from the neural crest while the non-pigmented cells are from the neuroectoderm, and tumors combining muscle cells and pigmented epithelial elements have links to teratomas $(4,14)$.

The 5-year survival rate in medulloblastoma is between $80 \%$ and $85 \%$. Although there are reports stating the prognosis of nodular medulloblastomas is more favorable, the prognostic reliability for histological subtypes is controversial (17).

\section{CONCLUSION}

Understanding the underlying mechanism of oncogenesis will serve as leverages for future treatment modalities. However, with the options of today's medicine we can not make a difference in treating various subtypes of medulloblastomas. In our opinion, this case together with the previously reported 6 cases of medulloblastoma with melanotic and myogenic differentiation supports the theory that medulloblastomas originate form pluripotent stem cells.

\section{REFERENCES}

1. ArunKumar MJ, Chacko G, Chandi SM, Chandy MJ: Medullomyoblastoma: A case report. Neurol India 47:55-57, 1999

2. Banerjee AK, Kak VK: Teratoid tumour of the cerebellum. J Pathol 111:285-287, 1973

3. Barger GR, Douglas JG, Kupsky WL, Sloan AE, Zak IT: Medulloblastoma, In: Berger MS, Prados MD, eds. Textbook of Neuro-Oncology. Philadelphia: Saunders, 2005: 253-269

4. Chi SN, Gardner SL, Levy AS, Knopp EA, Miller DC, Wisoff JH, Weiner HL, Finlay JL: Feasibility and response to induction chemotherapy intensified with high-dose methotrexate for young children with newly diagnosed high-risk disseminated medulloblastoma. J Clin Oncol 22:4881-4887, 2004

5. Chowdhury C, Roy S, Mahapatra A, Bhatia R: Medulloblastoma: A teratoma. Cancer 55:1495-1500,1985

6. Dolman $\mathrm{CL}$ : Melanotic medulloblastoma. Acta Neuropathol 76(5):528-531,1988

7. Duinkerke SJ, Slooff JL, Gabreëls FJ, Renier WO, Thijssen HO, Biesta JH: Melanotic rhabdomyomedulloblastoma or teratoid tumour of the cerebellar vermis. Clin Neurol Neurosurg 83:29-33, 1981

8. Kalimo H, Paljärvi L, Ekfors T, Pelliniemi LJ: Pigmented primitive neuroectodermal tumor with multipotential differentiation in cerebellum (pigmented medullomyoblastoma). A case with light- and electron-microscopic, and immunohistochemical analysis. Pediatr Neurosci 13:188-195,1987

9. Kunschner LJ, Lang FF : Medulloblastoma, In: Winn RH, ed. Youmans, Neurological Surgery. Philadelphia: Saunders, 2004:1031-1042 
10. Lantos PL, Louis DN, Rosenblum MK, Kleihues P: Tumours of the nervous system. In: Graham DI, Lantos PL, eds. Greenfield's Neuropathology. New York: Arnold Publishers, 2002:892

11. Louis DN, Ohgaki $H$, Wiestler OD, Cavenee WK, Burger PC, Jouvet A, Scheithauer BW, Kleihues P: The 2007 WHO Classification of Tumours of the Central Nervous System. Acta Neuropathol 114(2):97-109,2007

12. Mehta A, Patkar N, Nakra R, Nema S: A 3 1/2-year-old child with a posterior fossa mass. Pigmented medullomyoblastoma. Arch Pathol Lab Med 130:565-566, 2006

13. Nozza P, Milanaccio C, Piatelli G, Rossi A, Raso A, Cama A, Garré ML, Pietsch T: Cerebellar medullomyoblastoma with melanotic tubular structures. Pediatr Blood Cancer 50(1): 183-185, 2008
14. Polydorides AD, Perry A, Edgar MA: Large cell medulloblastoma with myogenic and melanotic differentiation: $A$ case report with molecular analysis. J Neurooncol 88(2):193197,2008

15. Sakata $H$, Kanamori $M$, Watanabe $M$, Kumabe $T$, Tominaga $T$ : Medulloblastoma demostrating multipotent differentiation: Case Report. Brain Tumor Pathol 25:39-43, 2008

16. Sarkar C, Deb P, Sharma MC: Recent advances in embryonal tumours of the central nervous system. Childs Nerv Syst 21(4):272-293, 2005

17. Son El, Kim IM, Kim DW, Yim MB, Kang YN, Lee SS, Kwon KY, Suh SI, Kwon TK, Lee JJ, Kim DS, Kim SP: Immunohistochemical analysis for histopathological subtypes in pediatric medulloblastomas. Pathol Int 53(2):67-73, 2003 